\title{
O użyteczności badań nad prawem rzymskim - refleksje na kanwie rozprawy Joanny Kruszyńskiej-Koli pt. Ratio przedawnienia
}

\author{
Abstract \\ On the Usefulness of Research into Roman Law - Some Reflections on the \\ Joanna Kruszyńska-Kola's Dissertation Ratio przedawnienia [The Ratio of \\ Prescription]
}

In this paper I present my personal opinion on the role of present-day research into the history of law, especially into Roman law, referring to the wider issue of the usefulness of Roman law in the future development of private law. I emphasize the clear deficit of communication between historians and proponents of modern law doctrine. This shortcoming is manifested in the lack of interest that lawyers tend to display in achievements in the field of legal history, and is proved more concretely by the fact that the references to the history in monographs on civil law are often only superficial and fragmentary. Unfortunately, legal historians rarely try to initiate any real dialogue with the practitioners of civil law doctrine. This approach offers a profound and compelling study, which both takes the present point of view into consideration and tackles many of the questions that are important and interesting today.

I intend to indicate at least some basic issues that should be taken into consideration by legal historians who want to pique other lawyers' interest in their works. In my opinion, the most important aspects are the choice of an attractive topic, that is not confined only to history; proper identification of the detailed issues, including such issues as are crucial and interesting today; and in-depth analysis of both current law and the discourse held in modern doctrine. It is significant to combine the appropriate historical methodology with the need for an attractive and communicative presentation of the research and its results.

In her dissertation on the ratio of prescription Joanna Kruszyńska-Kola proposes an excellent method for improving communication with proponents of modern law doctrine. I am convinced that her work brings substance to the vision of research into the history of law which is described in my paper, for that reason I demonstrate how the author managed to achieve the purpose that legal historians should be pursuing.

Keywords: importance of research into history of law, history of law, prescription, limitation of claim

Słowa kluczowe: znaczenie badań historycznoprawnych, historia prawa, preskrypcja, przedawnienie roszczenia 
Wśród historyków prawa od dawna, a z własnej perspektywy przez cały czas mojej pracy naukowej poświęconej badaniom nad prawem rzymskim, toczy się bardziej lub mniej ożywiona dyskusja na temat znaczenia historii prawa zarówno jako przedmiotu dydaktycznego wykładanego na studiach prawniczych, jak i dla współczesnego prawa, zwłaszcza wypracowywanych w nim nowych koncepcji i zmian w instytucjach czy też konstrukcjach prawnych, często sięgających rodowodem już starożytności. Każdemu romaniście znane są twierdzenia Henryka Kupiszewskiego, że w dniu wejścia w życie niemieckiego kodeksu cywilnego zniknął w Europie ostatni bastion bezpośredniego stosowania prawa rzymskiego ${ }^{1}$. Ostatecznie i nieodwołalnie przeszło wówczas do historii i stało się dyscypliną historyczną ${ }^{2}$. W warunkach ukształtowanych po wielkich kodyfikacjach narodowych mogło zachować jedynie stanowisko suflera $\mathrm{w}$ stosunku do prawa cywilnego, a wyjątkowo także w odniesieniu do innych dyscyplin prawniczych ${ }^{3}$. Te niewątpliwie trafne obserwacje stanowią punkt wyjścia w dyskusji nad współczesnym znaczeniem badań naukowych w prawie rzymskim, a w pewnym stopniu także szerzej nad rolą historii prawa jako dyscypliny naukowej i dydaktycznej.

W publikacjach i na konferencjach naukowych w dyskusji o użyteczności prawa rzymskiego lub historii prawa często wygłaszane są opinie, że jako historycy prawa mamy jeszcze wiele do zaproponowania, a efekty naszej pracy powinny zainteresować prawników parających się prawem pozytywnym. Jak stwierdza Marek Kuryłowicz, jurysprudencja bez historii działa po omacku, prawnik ślepy na historię jest wręcz niebezpieczny, bez studiów historycznoprawnych można zostać magistrem prawa, ale nie można być wówczas dobrym prawnikiem ${ }^{4}$. Uczony podejmujący zagadnienia współczesnego prawa styka się stale z problemem historycznego kształtowania się badanych instytucji prawnych, z zagadnieniami ich rozwoju jako wyniku określonych tendencji i przyczyn, jakie legły u ich historycznych podstaw ${ }^{5}$. Bez uwzględnienia elementu historycznego nie można wniknąć dostatecznie głęboko w prawo współczesne, a tym bardziej w kulturę prawną ${ }^{6}$. Z kolei Witold Wołodkiewicz zauważa, że prawo rzymskie, jeżeli ma odzyskać swoje znaczenie wśród dyscyplin prawniczych, powinno umożliwić prawnikowi współczesnemu patrzenie na teraźniejszość prawa i rozumienie korzeni, z których ona wyrasta. Zadaniem prawa rzymskiego jest umożliwienie dialogu $\mathrm{z}$ dyscyplinami prawa pozytywnego ${ }^{7}$. Myślę, że historyków prawa nie trzeba przekonywać, że oceny te są uzasadnione, problem wszakże w tym, czy tak uważają również inni, zwłaszcza przedstawiciele dyscyplin prawa pozytywnego.

Niekiedy da się usłyszeć bardziej pesymistyczny osąd, że cywiliści już dawno przestali się interesować tym, o czym piszemy, i nie dostrzegają potrzeby szerszego

\footnotetext{
1 Kupiszewski, Prawo rzymskie a współczesność, 105.

2 Ibid., 119.

3 Ibid., 28 i n.

${ }^{4}$ Kuryłowicz, Prawo rzymskie, 8.

5 Ibid., 158 i n.

6 Ibid., 159.

7 Wołodkiewicz, „Prawo rzymskie w XXI wieku”, 120.
} 
uwzględnienia argumentów historycznych w swoich pracach ani też wnikliwszego spoglądania we własnych badaniach z perspektywy historycznej. Niestety muszę przyznać, że ten bardziej pesymistyczny pogląd wydaje się bliższy prawdy, wspomniana perspektywa historyczna zwykle bowiem przybiera już tylko wymiar podrozdziału, czasami rozdziału, monografii cywilistycznej stanowiącej tak zwaną pracę na stopień. I tu jednak rzadko można mówić o gruntownych badaniach historycznych, z bezpośrednim dostępem do źródeł i przy wykorzystaniu wystarczająco bogatej literatury, a przede wszystkim o wyciąganiu z tych badań jakichś wniosków użytecznych obecnie. Pomimo tego, że fundamentalne dla rozwoju prawa prywatnego Digesta Justyniańskie są od dawna przetłumaczone na języki nowożytne, w tym ostatnio także na język polski ${ }^{8}$, trudno spotkać w owym ,rozdziale historycznym” monografii cywilistycznych choćby krótką analizę któregoś z ich fragmentów. To zatem nie słaba znajomość łaciny, lecz brak odczucia potrzeby sięgnięcia bezpośrednio do źródeł, stanowi przyczynę takiego podejścia. Często rozdział „historyczny” stanowi mniej lub bardziej udaną kompilację podstawowych podręczników do historii prawa, wspartą kilkoma artykułami naukowymi, w większości w języku polskim, na dany temat. Jest to też zwykle część pracy napisana sama dla siebie, poniekąd z obowiązku, do której nie następują później głębsze odniesienia. Solidniejsze prezentacje historycznego kształtowania się podjętego w monografii zagadnienia owszem zdarzają się, ale odnoszę wrażenie, że stanowią mniejszość. O ile komparatystyka ma dla cywilisty fundamentalne znaczenie, a wielu uważa nawet, że monografia musi zawierać rozbudowany rozdział poświęcony prawom obcym, o tyle perspektywa historyczna jest raczej marginalizowana. Tymczasem obie perspektywy są ważne i nie można prowadzić rzetelnych badań prawnoporównawczych, zwłaszcza w obszarze prawa cywilnego, bez wnikania w historię.

Brak szerszego korzystania z dorobku historii prawa jest tym bardziej widoczny w praktyce stosowania prawa, zwłaszcza w orzecznictwie, co najwyżej bowiem można tu, i to w niewielkim odsetku uzasadnień orzeczeń ${ }^{9}$, odnaleźć sentencję łacińską, zwykle wywodzącą się ze źródeł antycznych, albo też zauważa się rzymski rodowód jakiegoś pojęcia czy konstrukcji prawnej, wszakże zwykle bez bliższego opisu ich antycznego obrazu $^{10}$. Pomimo tego, że na co dzień studiuję sporo orzeczeń Sądu Najwyższego i sądów apelacyjnych tylko zupełnie wyjątkowo odnajduję wyrok, w którym choćby trochę głębiej sięgnięto by do prawa rzymskiego ${ }^{11}$. Paremie służą niemal z reguły zgrabnemu podsumowaniu argumentacji sądu wywodzonej z przepisu prawa, dotychczasowych po-

${ }^{8}$ Dokonał tego zespół pod kierownictwem Tomasza Palmirskiego (UJ), a tłumaczenie ukazywało się w kilku sukcesywnie publikowanych tomach w latach 2013-2017 (Palmirski, Digesta Iustiniani).

${ }^{9}$ Według ustaleń Witolda Wołodkiewicza w latach 1971-2001 łacińskie paremie prawnicze zostały użyte w 1,57\% orzeczeń Trybunału Konstytucyjnego, Sądu Najwyższego, Naczelnego Sądu Administracyjnego i wybranych sądów apelacyjnych (Wołodkiewicz, „Łacińskie paremie prawnicze”, 10). Zestawienie sentencji ze wskazaniem orzecznictwa, w których zostały przywołane, zawiera praca Ewy Gajdy i Bożeny Lubińskiej (zob. Gajda, Lubińska, Łacińska terminologia prawnicza, 583 i n.

${ }_{10}$ Tylko dla przykładu zob. ostatnio wyrok SN z dnia 24 czerwca 2010 r., IV CSK 67/10; postanowienie SN z dnia 20 marca 2014 r, I CSK 404/13; wyrok SN z dnia 9 sierpnia 2016 r., II CSK 760/15; wyrok SN z dnia 27 lipca 2018 r., V CSK 401/17; wyrok SN z 16 dnia maja 2019 r., III CSK 40/17; postanowienie SN z 26 dnia listopada 2019 r., IV CSK 418/18.

11 Zob. wyrok SN z dnia 31 marca 2020 r., II CSK 124/19. Co interesujące krótka uwaga dotycząca rzymskiego procesu cywilnego znalazła się w wyroku sądu karnego. Wyrok SN z dnia 17 listopada 2014 r., III KK 236/14. 
glądów orzecznictwa lub doktryny prawa. Jest to zatem zwykle popis erudycji składu orzekającego, a nie właściwa przesłanka rozstrzygnięcia. Prawo rzymskie cieszy się pewną estymą, przynajmniej u części praktyków, ale znajduje to wyraz „na poziomie haseł" i stwierdzeń, że ,już w prawie rzymskim...”. Jest to wszakże zrozumiałe, skoro prawo rzymskie już od bardzo dawna nie jest bezpośrednio stosowane, a sąd musi oprzeć się na treści przepisu, wspartej wykładnią orzeczniczą i doktrynalną. Nieco głębsze odniesienia do prawa rzymskiego można natomiast znaleźć w orzecznictwie Trybunału Sprawiedliwości Unii Europejskiej, tu rzeczywiście argumenty wywodzone z prawa stanowiącego fundament współczesnego prawa cywilnego państw członkowskich mają niekiedy samodzielne znaczenie ${ }^{12}$.

Za ten niesatysfakcjonujący stan komunikacji historyków prawa i przedstawicieli dyscyplin prawa pozytywnego nie obwiniam bynajmniej tych ostatnich i nie oczekuję od nich równie pogłębionych badań historycznych jak od historyków prawa. Każda dyscyplina naukowa rządzi się po części własnymi prawami i wymaga nieco innych umiejętności i zainteresowań, nawet jeżeli wciąż mieści się pod szerokim parasolem nauk prawnych. Uważam, że to historycy prawa mają na tym polu wiele do zrobienia, aby uczynić własne prace, zwłaszcza pisane zwykle z mozołem i latami monografie, atrakcyjnymi dla reszty prawników, a nie tylko kolegów po fachu.

Bardzo wiele zależy tu już od wyboru przedmiotu badań, romanista bowiem poszukujący tematu choćby na artykuł w czasopiśmie naukowym zwykle przekonuje się, że w literaturze światowej już napisano na ten temat dużo i trudno będzie zaproponować coś oryginalnego i dającego się obronić przed ewentualną krytyką, dodajmy głównie ze strony kolegów romanistów, od recenzentów poczynając. Tym bardziej jeżeli romanista postawi sobie za cel opracowanie którejś z „klasycznych” instytucji, jakie przetrwały we współczesnych kodeksach cywilnych, z nadzieją, że zainteresuje tym cywilistów, zwykle sam szybko nabiera wątpliwości, czy jego praca będzie miała jakikolwiek walor oryginalności, a nie pozostanie w najlepszym razie zgrabnym opracowaniem i uporządkowaniem poglądów nauki. Z kolei wybór problematyki mniej klasycznej i poszukiwanie wątków niszowych z reguły ogranicza możliwość zainteresowania wynikami badań cywilistów, a praca owszem jest czytana, ale głównie przez kolegów z innych ośrodków i pasjonatów zainteresowanych historią.

W ciągu ostatnich kilkunastu lat w polskiej romanistyce powstało wiele solidnie opracowanych monografii, opartych na gruntownych badaniach źródłowych i często imponującej, wielojęzycznej literaturze, ale w większości zamykają się one na antyku i co najwyżej fragmentarycznie lub dopiero w zakończeniu nawiązują do prawa współczesnego, zwykle na poziomie dość prostych porównań lub prób wykazania trwałości myśli jurystów rzymskich. Często monografia, choć sama w sobie jest znakomita, podejmuje tematykę, co do której z góry można założyć, że zainteresuje jedynie kolegów historyków prawa. Można odnieść wrażenie, że podobnie jak wielu cywilistów zadowala się „historycznym wstępem” w charakterze jedynie ornamentu, tak część romanistów zadowala się podobnym ornamentem w postaci ograniczonych przedmiotowo i niepogłębionych nawiązań do prawa współczesnego albo rezygnuje nawet i z tego. Taka postawa jest jednak w pewnym stopniu zrozumiała, w końcu każdy z nas obawia się zarzutu

${ }^{12}$ Zob. Sobczyk, „Prawo rzymskie”, 279-94. 
ahistorycyzmu czy też przenoszenia współczesnych wyobrażeń i współczesnego sposobu myślenia na analizę materiału źródłowego. Trudno jest z przekonaniem poszukiwać w Digestach rozwiązań problemów postawionych nie przez samych Rzymian, tylko przez dogmatykę współczesną, łatwo tu bowiem o zarzut, że „Rzymianie wcale tak tego nie pojmowali” lub „tym się w ogóle nie zajmowali”. Nie ma też co ukrywać, że każdy czuje się pewniej na własnym polu i z nieśmiałością podejmuje współczesne wątki dogmatyczne, dostrzegając ryzyko, że cywilista skrytykuje pracę, choćby ze względów metodologicznych lub dlatego, że nie odnajdzie w niej akurat tego, czego poszukiwał, a reszty nie doceni, ponieważ nie bardzo go ona interesuje.

Nie chciałbym, aby czytelnik odebrał powyższe uwagi jako krytykę, być może niesprawiedliwą, swojego środowiska. Uważam bowiem, że każdy ma prawo do własnych zainteresowań badawczych i powinien być oceniany przez pryzmat tego, czy rzetelnie przeprowadził badania z perspektywy założeń jego dyscypliny. Nie zamierzam deprecjonować cudzych badań tylko dlatego, że mnie by ten temat nie zainteresował lub podkreśliłbym w nim inne wątki albo oczekiwał szerokiej analizy także prawa współczesnego. Wielu romanistów obecnie bardziej zajmuje się szeroko pojętym prawem publicznym niż prywatnym, przywiązuje większą wagę do wykazania tła historycznego, także filozofii i antycznej literatury, a ja ich nie tylko szanuję, ale podziwiam za to, choć sam jednak zdecydowanie wolę analizę jurydyczną prawa prywatnego.

Powyższe uwagi czynię w ogóle nie po to, aby kogokolwiek skrytykować, lecz po to, aby zwrócić uwagę na problem, jak trudno jest odnaleźć się historykowi prawa w materii prawa współczesnego, a z kolei doktrynie prawa współczesnego w historii prawa. Skutkiem tego jest niewielki stopień komunikacji obu dyscyplin. Nie chcę także, aby powyższe wywody zostały odczytane jako zachęta do prowadzenia jedynie takich badan, które mogą zainteresować doktrynę współczesną, aczkolwiek prawdą jest, że dobrze, aby było ich jak najwięcej.

Można też postawić mi zarzut, że podnoszę w tym miejscu zupełnie sztuczne problemy, lepiej zajmujmy się tym, na co mamy ochotę, a jeżeli nie zainteresuje to doktryny prawa współczesnego, to jej problem. Owszem, tak też można, i to nawet ze sporym powodzeniem. Przy takim podejściu nie dziwmy się jednak postępującemu osłabianiu znaczenia naszych badań dla prawa współczesnego i znaczenia przedmiotów historycznoprawnych, redukcji godzin dydaktycznych oraz niewielkiemu zainteresowaniu studentów naszymi seminariami. Trudno na wszelkich komisjach programowych bronić swój przedmiot przed atakami kolegów zajmujących się prawem pozytywnym, skoro wielu z nich uważa, że zajmujemy się „starociami”, a studia powinny być jak najbardziej praktyczne.

\section{II}

Wybierając problematykę rozprawy doktorskiej lub habilitacyjnej historyk prawa staje przed nie lada wyzwaniem: z jednej strony chce, aby docenili ją inni historycy prawa i poszukuje tematyki, która daje szansę na jakiś oryginalny wkład własny, a z drugiej strony wielu badaczy marzy jeszcze o tym, żeby po pracę sięgnęli także naukowcy zaj- 
mujący się na co dzień prawem współczesnym. Wymaga to doboru atrakcyjnego tematu, zakreślenia odpowiednich szczegółowych problemów badawczych i zastosowania prawidłowej metodologii, zarówno właściwej z punktu widzenia założeń uprawianej dyscypliny, jak i atrakcyjnej dla czytelnika, który zajmuje się czymś bardzo pokrewnym, ale w nieco inny sposób. Typowa praca oparta na źródłach osadzonych w konkretnym miejscu i czasie raczej nie spotka się z szerszym zainteresowaniem, jeżeli jej temat $\mathrm{i}$ wątki szczegółowe nie będą nawiązywały do prawa współczesnego i problemów w nim obecnym. Nawet wybór „klasycznej” problematyki, obecnej także we współczesnym kodeksie, nie gwarantuje sukcesu, jeżeli obrane zagadnienie nie będzie opracowane komunikatywnie dla czytelnika cywilisty lub karnisty, w sposób, który go nie znuży po lekturze kilku stron. Nic też dziwnego, że wielu współczesnych historyków prawa poszukuje odpowiedniej metody prowadzenia badań i prezentacji ich wyników. Udanym przykładem takich poszukiwań jest praca dr Joanny Kruszyńskiej-Koli dotycząca ratio przedawnienia ${ }^{13}$.

\section{III}

Dr Joanna Kruszyńska-Kola jest adiunktem w Zakładzie Prawa Rzymskiego, Tradycji Prawnych i Prawa Dziedzictwa Kulturowego Wydziału Prawa i Administracji Uniwersytetu Adama Mickiewicza w Poznaniu i uczennicą profesora Wojciecha Dajczaka. Jest zatem zasadniczo historykiem prawa, przynajmniej z punktu widzenia formalnej przynależności w strukturze wydziału, a praca dotycząca ratio przedawnienia stanowi nieco zmienioną i zaktualizowaną publikację jej dysertacji doktorskiej ${ }^{14}$. Rozprawa stanowi jednak dowód tego, że zainteresowania Autorki nie ograniczają się do historii prawa, przeciwnie bardzo dobrze orientuje się ona także w niuansach współczesnego prawa cywilnego i to także w ujęciu prawnoporównawczym. Jako recenzentowi w przewodzie doktorskim i recenzentowi wydawniczemu nie wypada mi w tym miejscu sporządzać klasycznej, wieloaspektowej recenzji pracy, na ten temat się już wypowiedziałem, a zainteresowani mogą się z moją recenzją zapoznać na stronie internetowej Centralnej Komisji ds. Stopni i Tytułów. Nie taki też jest cel niniejszego artykułu. Ograniczę się zatem do konstatacji, że pracę tę oceniłem bardzo wysoko i przejdę od razu do próby wykazania, że stanowi ona godną rozważenia propozycję prowadzenia badań w historii prawa.

13 Kruszyńska-Kola, Ratio przedawnienia.

14 Rozprawa ta nosiła nieco dłuższy tytuł (Ratio przedawnienia. Dylematy europejskiej tradycji prawnej w świetle historyczno-porównawczej analizy prawa francuskiego i polskiego) i była jeszcze obszerniejsza. Obrona odbyła się w styczniu 2019 r. 


\section{IV}

Uważam, że podstawowym warunkiem uzyskania szerszego zainteresowania wynikami przeprowadzonych badań jest odpowiedni wybór tematu. Już sam tytuł powinien w sposób jednoznaczny informować, że problematyka zainteresuje nie tylko wąskie, czy nawet bardzo wąskie grono specjalistów z danej dziedziny, ale także czytelnika, który styka się z tą problematyką na co dzień zajmując się zasadniczo czymś innym niż autor pracy. Tytuł Ratio przedawnienia z całą pewnością nie sugeruje zawężenia przedmiotu pracy do badań historycznoprawnych, wręcz przeciwnie, od razu wskazuje na to, że jest znacznie szerszy i obejmuje także prawo współczesne. Można nawet powiedzieć, że gdyby rozprawa ograniczała się do prawa rzymskiego, romanista zatytułowałby ją inaczej, aby uniknąć właśnie skojarzeń ze współczesnością. Niejeden romanista postawiłby zarzut, że już sam tytuł świadczy o tym, że dotyczy ona problemów „nierzymskich”, tj. takich, które zwykle nie zainteresowały samych jurystów, lecz stanowi bardziej emanację współczesnego spojrzenia na źródła prawa rzymskiego. Byłby to zarzut prawdziwy, ale tylko po części, autorka bowiem analizuje źródła rzymskie, w których rzeczywiście można się doszukać odniesień do ratio przedawnienia.

Przedmiot badań wzmiankowanej rozprawy nie ogranicza się do prawa rzymskiego ani nawet do historii prawa, albowiem obszernie odnosi się także do prawa współczesnego. Autorka wydzieliła w pracy trzy rozdziały o bardzo rozbudowanej i wielopoziomowej strukturze wewnętrznej. Pierwszy dotyczy ograniczeń czasowych skarg w prawie rzymskim, drugi ratio przedawnienia we francuskim prawie prywatnym, począwszy jeszcze od epoki poprzedzającej kodeks Napoleona, a trzeci ratio przedawnienia w polskim prawie prywatnym, począwszy od prac przygotowawczych kodeksu zobowiązań. Te trzy rozdziały stanowią w istocie trzy części pracy, z których każda poświęcona jest badaniu zarówno głównego przedmiotu pracy, jak i zagadnień szczegółowych w wymienionych trzech porządkach prawnych. Siła rzeczy pierwszy przynależy w całości do historii prawa, dwa następne zaś po części odnoszą się do historii prawa, a po części stanowią opracowania, które bez cienia wątpliwości można zaliczyć do dorobku doktryny prawa współczesnego i to jeszcze w dwóch różnych porządkach prawnych.

Co istotne, każdy z rozdziałów zawiera głęboką, wręcz drobiazgową i stojącą na bardzo wysokim poziomie analizę podjętych wątków szczegółowych. Zarówno zatem prawo rzymskie nie zostało tu potraktowane jako pisany z obowiązku i bez entuzjazmu historyczny wstęp do monografii traktującej o prawie współczesnym, jak i prawo cywilne nie jest tu jedynie wisienką na torcie czy też swoistym apendyksem do badań historycznoprawnych. W mojej ocenie ta bardzo obszerna monografia (620 stron merytorycznych) łączy w sobie w istocie trzy odrębne monografie na ten sam temat i każda z nich z osobna broniłaby się jako doktorat czy to z prawa rzymskiego, historii prawa, czy to z prawa cywilnego. Mamy tu zatem swoiste „trzy w jednym” i pracę w pewnym sensie interdyscyplinarną. Nie jest to może zabieg zupełnie nowy w naszej rodzimej romanistyce, jednakże w tych rozmiarach i w takim stopniu wnikliwości wywodu z pewnością bardzo rzadki.

Sam fakt, że ratio przedawnienia w prawie cywilnym francuskim i polskim została tu bardzo obszernie i wnikliwie przedstawiona powoduje, że praca ta z powodzeniem może 
być adresowana do cywilistów, z których ufam, że spora część przy okazji sięgnie także do rozważań historycznych, w tym prawa rzymskiego. Obrana koncepcja prezentacji tematu sprzyja więc zainteresowaniu cywilistów dorobkiem romanistyki na tym polu. Istnieje zatem szansa nawiązania dialogu interdyscyplinarnego i redukcji owego deficytu komunikacji. Przede wszystkim jednak J. Kruszyńska-Kola udowodniła tu, że badania historycznoprawne są w ogóle potrzebne i że dostarczają argumentów w poszukiwaniu rozstrzygnięć wielu nurtujących współcześnie cząstkowych problemów na tle instytucji przedawnienia, a zwłaszcza jej ratio. Praca stanowi zachętę, że warto solidnie podjąć obrany przedmiot badań przekrojowo i przeprowadzić go od antyku do współczesności, bez ograniczania się jedynie do prostych nawiązań czy też porównań. Co więcej, autorka udowodniła, że takie rzetelne przekrojowe ujęcie jest w ogóle możliwe, z pewnością bardzo praco- i czasochłonne, wymagające szerokiego spojrzenia i sporych umiejętności analitycznych, ale jednak wykonalne.

Sukces w nawiązaniu komunikacji z doktryną prawa współczesnego zależy także od odpowiedniego doboru cząstkowych problemów badawczych, powinny to bowiem być problemy podejmowane zarówno z perspektywy historycznego jurysty lub legislatora, jak i dzisiejszej. Podporządkowana temu powinna być czytelna i uzasadniona merytorycznie struktura rozprawy. Czytelnik powinien już w spisie treści zidentyfikować zagadnienia, z którymi kiedyś sam się zetknął lub które mogą go zainteresować i poczuć, że sam posiada wystarczającą wiedzę, aby zmierzyć się z lekturą pracy. Dobór zagadnień powinien czytelnika zainteresować, wzbudzić przekonanie, że ma do czynienia z porządną analizą jurydyczną i pozwolić mu odnieść problematykę pracy do tego, co już wie na ten temat, zanim zacznie ją czytać. Nawet najstaranniej opracowane niuanse rozstrzygnięć jurystów rzymskich nie zainteresują cywilisty, jeżeli uzna on, że nie jest mu to przydatne lub co gorsza, że mało z tego rozumie. Trudno oczekiwać od czytelnika, żeby zajął się lekturą, która jest dla niego nużąca i trudna, zwłaszcza jeśli nie ma poczucia, że sam się w jakiś sposób przy tym wzbogaca. Oczywiście tu bardzo łatwo trafić na zarzut ahistorycyzmu, roztrząsania zagadnień, które nie wynikają wprost ze źródeł, podejmowania problemów obcych historycznemu prawodawcy, ale można to jednak zrobić tak, żeby przed tym zarzutem się obronić, wykazaniem poprawnej metodologicznie analizy źródła i problemów wprost w nim podjętych. W moim przekonaniu jeżeli praca stanowi rzetelne opracowanie źródeł, to fakt, że jej autor przy okazji spojrzał na nie z perspektywy współczesnej nie może stanowić wady, wręcz przeciwnie, jest to jej zaleta. Aczkolwiek nie mam tu na myśli banalnych porównań czynionych na siłę lub też doszukiwania się wszędzie korzeni antycznych. Zalecane jest też formułowanie wniosków z analizy źródeł zarówno cząstkowych, jak i podsumowujących dany rozdział, a nawet podrozdział. Przy pracy obszernej i dotyczącej złożonej problematyki jest to wręcz konieczne. Wnioski te muszą przy tym być formułowane w taki sposób, aby można było do nich wracać w toku analizy prawa kolejnych epok i prawa współczesnego, co wymusza spojrzenie na historię prawa z perspektywy specjalisty w prawie współczesnym. Autorka czyni to wzorowo, oferując częste podsumowania podjętych wątków na różnych poziomach struktury pracy i to w taki sposób, aby najważniejsze wnioski można było przywołać w konfrontacji z wnioskami z innego systemu prawnego.

W każdym z trzech rozdziałach rozprawy J. Kruszyńska-Kola podejmuje podobne problemy, choć z uwzględnieniem specyfiki prawa rzymskiego, w którym o przedawnie- 
niu skarg można mówić dopiero od konstytucji Teodozjusza II (C. Th. 4,14,1) z 424 r., aczkolwiek wcześniej niektóre skargi były dotknięte ograniczeniami czasowymi (actiones temporales $)^{15}$. W prawie klasycznym sama idea, że uprawniony powinien mieć możliwość wniesienia skargi tylko przez określony czas (np. pół roku, rok, pięć lat) była Rzymianom znana, ale realizowana wąsko wobec zasady wieczystości skarg, dopiero we wzmiankowanej konstytucji uznano ogólną zasadę przedawnienia skarg. Podjęty temat nie jest więc wdzięczny z punktu widzenia romanisty, skoro traktuje o czymś, co samym Rzymianom okresu największego rozkwitu jurysprudencji było znane tylko w ograniczonym stopniu. Nadto przeprowadzana analiza nie miała na celu po prostu opisu antycznych korzeni instytucji przedawnienia, z naciskiem na jej ratio, lecz musiała uwzględniać szczegółowe problemy badawcze szeroko podjęte w dwóch następnych rozdziałach. Innymi słowy sposób prezentacji wyników badań musiał godzić konieczność podjęcia prawdziwych ustaleń historycznych z potrzebą częstego nawiązywania do nich w pozostałej części pracy. Słusznie autorka potraktowała część poświęconą prawu rzymskiemu jako przedmiot odniesienia w szczegółowych rozważaniach poświęconych prawu francuskiemu i polskiemu. Stąd też w stosunku do materiału antycznego stawia takie problemy, jak przedmiot przedawnienia, początek biegu terminu, jego zawieszenie i przerwanie.

W pozostałych dwóch rozdziałach oprócz ich bardzo rozbudowanej wielopoziomowej struktury zwraca uwagę symetryczność, ponieważ podejmowane są w nich zasadniczo te same kwestie i w tej samej kolejności w drugim rozdziale w prawie francuskim, a w trzecim w prawie polskim, i w obu przypadkach ewolucyjnie w długiej perspektywie historycznej. Kryterium wydzielenia paragrafów jako podstawowej podjednostki rozdziałów odpowiadającej zwykle podrozdziałowi jest jak najbardziej merytoryczne, ujęte z uwagi na szczegółowe problemy dogmatyczne, a nie po prostu chronologiczne. Oczywiście podstawowy w badaniach historycznych wymóg chronologii i tu został zachowany, ale w ramach jednostek odpowiadających szczegółowym problemom dogmatycznym. Zabieg ten, absolutnie celowy i wręcz po mistrzowsku przeprowadzony, jest jedną z najważniejszych zalet pracy i to zwłaszcza on powoduje, że może ona zainteresować także cywilistów.

Wśród zagadnień szczegółowych praca traktuje zwłaszcza o samym pojęciu przedawnienia, jego przedmiocie, skutku oraz terminie (włącznie z początkiem, zawieszeniem i przerwaniem biegu przedawnienia), a także możliwości umownego modyfikowania regulacji przedawnienia. W ramach poszczególnych paragrafów podjęte zostały jeszcze bardziej szczegółowe kwestie, na przykład sposób uwzględniania przedawnienia w procesie, zrzeczenie się zarzutu przedawnienia, uzasadnienie dla wprowadzenia terminów szczególnych, sposób ustalania długości terminów. Jak widać choćby z powyższego przeglądu, identyfikując główne problemy badawcze i przygotowując strukturę rozprawy, autorka myślała bardziej jak cywilistka niż historyk prawa, koncentrując się na aspektach stricte jurydycznych. Wskutek tego każdy prawnik, który choćby przejrzy monografię, od razu dostrzeże wątki, które w jakimś stopniu są mu znane i które mogą go zainteresować. Wielu odczuje potrzebę bliższego zapoznania się z jej treścią i zapewne

15 Znakomicie znana Rzymianom była zaś inna instytucja związana z upływem czasu - zasiedzenie (usucapio i longi temporis praescriptio). 
nie pominie rozważań o znaczeniu już tylko historycznym. Każdy czytelnik, który zwykle nie para się historią prawa, będzie miał okazję wniknąć w tę historię, a już zwłaszcza nie wyobrażam sobie, żeby autorzy przyszłych monografii cywilistycznych dotyczących jakichś aspektów przedawnienia nie sięgnęli do tej pracy. Uważam wręcz, że J. Kruszyńska-Kola oferuje im produkt, którego poszukują w celu przygotowania owego „historycznego wstępu” ich monografii, przedstawia bowiem bardzo rzetelny i obszerny opis instytucji przedawnienia, a nie tylko jej ratio w jej rozwoju historycznym, czyniąc to w sposób całkowicie komunikatywny i prawidłowy metodologicznie. Nie można tego w ogóle porównać $\mathrm{z}$ wertowaniem podręczników do historii prawa z nadzieją odnalezienia jakichś szczegółów, które złożą się na choćby bardzo ogólny obraz przedawnienia w prawie rzymskim $\mathrm{i}$ w toku dalszej historii prawa albo też z koniecznością przeglądania katalogów wielu bibliotek i sprowadzania dzieł co do zasady obcojęzycznych i trudnych w odbiorze dla niespecjalistów. Myślę, że wielu autorów przygotowujących prace z zakresu prawa cywilnego zdążyło zauważyć, jak mozolna i trudna jest praca historyka prawa, dla niektórych przeszkodą byłaby już potrzeba lektury literatury w wielu językach ${ }^{16}$, więc takie dzieło, jak Ratio przedawnienia staje się nieocenioną pomocą.

W mojej ocenie kolejnym warunkiem zainteresowania badaczy prawa współczesnego dorobkiem historyków prawa jest to, aby prace historyków w ogóle postawiły sobie taki cel, nie poprzestając na prawidłowej metodologicznie analizie źródeł i wyciąganiu z nich bezpiecznych, dających się bronić wniosków, którymi może się zainteresować co najwyżej inny historyk lub pasjonat historii. Jeżeli chcemy nawiązać dialog z doktryną prawa pozytywnego, sami powinniśmy ten dialog inicjować. Konieczne jest do tego nie tylko szerokie uwzględnienie prawa obecnie obowiązującego, ale także bogate nawiązywanie $\mathrm{w}$ toku jego analizy do ustaleń badań historycznoprawnych, zwracanie uwagi na podobne problemy, zbliżone lub odmienne rozwiązania oraz ich przesłanki. Czytelnik musi rzeczywiście widzieć to, że prawo, zwłaszcza cywilne, jest w ogromnym stopniu produktem wielowiekowej ewolucji, a nie zostało obmyślane ex nihilo przez komisję kodyfikacyjną przygotowującą swego czasu kodeks. Najlepiej zrobić to, przypominając czytelnikowi, że ten szczegółowy aspekt analizowanego zagadnienia już kiedyś był przedmiotem rozważań prawników, i że sformułowano wtedy pomysły i koncepcje godne zastanowienia i dzisiaj. Akurat autorka czyni to bardzo często i bardzo precyzyjne. Poznając kolejne rozdziały pracy, czytelnik przekonuje się, że poprzednie rozważania były podejmowane m.in. po to, aby głębiej poddać analizie jaką́s szczegółową kwestię francuskiej czy polskiej regulacji przedawnienia roszczeń i dotyczących jej poglądów orzeczniczych lub doktrynalnych. Poza tym bardzo cenne jest już samo dokonywanie porównań kilku porządków prawnych, gdyż łatwo wtedy zauważyć, że przyjęte w danym systemie prawnym rozwiązanie wcale nie jest jedynie możliwe do wyobrażenia, lecz stanowi zwykle jedną z kilku propozycji. Dość wspomnieć, że doświadczenie prawa rzymskiego stanowi, że potrzeba funkcjonowania instytucji przedawnienia wcale nie jest oczywista, w końcu dopiero w V w. wprowadzono ogólną zasadę przedawnienia skarg. Śledząc w rozprawie szczegółową analizę każdego z cząstkowych aspektów przedawnienia, czytelnik dochodzi do wniosku, że w tej instytucji mało, a być może nawet nic

${ }^{16} \mathrm{~W}$ omawianej pracy autorka skorzystała $\mathrm{z}$ bardzo wielu prac $\mathrm{w}$ językach francuskim, niemieckim, angielskim i włoskim, a trzeba zauważyć, że kolejnym podstawowym językiem romanistyki jest hiszpański, często też zachodzi potrzeba lektury języków słabiej znanych, np. niderlandzkiego. 
nie jest oczywiste, z reguły bowiem wobec przyjętego rozwiązania da się wskazać rozsądną i godną rozważenia alternatywę lub kilka konkurencyjnych rozwiązań. Żeby nie szukać skomplikowanych przykładów, wcale nie przekonuje mnie skrócenie w 2018 r. $^{17}$ ogólnego terminu przedawnienia roszczeń majątkowych z 10 do 6 lat, ponieważ zauważam, że czasami nawet termin dziesięcioletni nie jest wystarczająco długi, aby należycie chronić interes wierzyciela. Tak istotna decyzja powinna zostać podjęta przez pryzmat ratio przedawnienia, jej ocena doktrynalna także powinna uwzględniać tę ratio lub rationes.

Rozprawa znakomicie wykazuje konflikt interesów wierzyciela i dłużnika istotny niemal w każdym z podjętych aspektów szczegółowych przedawnienia. Za każdą stroną tej gry interesów stoją ważkie argumenty, mające istotny wpływ na treść relewantnych przepisów kodeksu oraz ich wykładnię w orzecznictwie. Ten konflikt widać nie tylko w najłatwiej dostrzegalnym i najbardziej uchwytnym problemie samej długości terminu przedawnienia, ale także $w$ wielu innych miejscach. Należy wspomnieć, że ostatnio spore kontrowersje wzbudza problem przerwania biegu przedawnienia wnioskiem o zawezwanie do próby ugodowej, a zwłaszcza już drugim i kolejnym wnioskiem dotyczącym tego samego roszczenia. Instrument od dawna traktowany jako patent na faktyczne wydłużenie terminu przedawnienia nagle został znacząco zakwestionowany, w szczególności w tych przypadkach, w których już prima facie widać, że wnioskujący wcale nie liczył na zawarcie ugody, lecz tylko zapobiegał przedawnieniu roszczeń. Rozstrzygając tę kwestię, można podać istotne argumenty za każdym z przeciwstawnych rozwiązań i siłą rzeczy nie da się uciec od samej istoty przedawnienia i celów, którym ma ono służyć. Szerokie uwzględnienie przedawnienia, także z perspektywy historycznej, znacznie poszerza horyzonty oceny i ułatwia rozstrzygnięcie problemu.

\section{V}

Sukcesowi rozprawy łączącej historię prawa i prawo współczesne niewątpliwie sprzyja to, że autor, opierając się na doświadczeniach historycznych, dokonuje oceny obowiązującego prawa, stawia postulaty de lege ferenda lub proponuje rozwiązania problemów nurtujących współczesną doktrynę prawa i orzecznictwo. Rozprawa nie powinna poprzestawać na samym ustaleniu historycznego stanu rzeczy, nawet jeżeli zawierałaby i w tym aspekcie spory wkład własny, lecz powinna zawierać jakieś propozycje na przyszłość, choć uzasadnione przede wszystkim argumentami wywodzonymi z historii prawa. W tym aspekcie sposób myślenia historyka prawa i przedstawiciela doktryny prawa pozytywnego jest nieco inny. Historyk prawa ma niewątpliwie za zadanie ustalić prawdę historyczną, stan prawa w jakiejś kwestii w określonym miejscu i czasie, a nie myśleć prospektywnie. Tym samym jeżeli historyk prawa coś proponuje, to będzie to raczej hipoteza co do określonej treści regulacji prawnej, praktyki jej stosowania lub po prostu wykładni źródła. Od prawnika przygotowującego publikację naukową dotyczącą prawa współczesnego, a już zwłaszcza pracę na stopień, wymaga się czegoś więcej, nie powi-

\footnotetext{
${ }^{17}$ Ustawa z dnia 13 kwietnia 2018 r. o zmianie ustawy - Kodeks cywilny oraz niektórych innych ustaw.
} 
nien on bowiem zadowolić się tylko przyzwoitym opisem poglądów orzecznictwa i doktryny w danej kwestii, lecz powinien zaproponować coś nowego od siebie. Mile widziane są racjonalna krytyka obowiązującego stanu prawnego i postulaty de lege ferenda. Moim zdaniem wartościowa praca cywilistyczna powinna zawierać te elementy, a nie stanowić jedynie kompilacji lub komentarza. Siłą rzeczy historyk prawa nie przyjmuje takiej perspektywy i zwykle nie usiłuje proponować czegoś na przyszłość. Nie oznacza to jednak, że stawianie postulatów zmian regulacji prawnej lub propozycje określonej wykładni przepisów przez historyków są zupełnie wykluczone. Przeciwnie, tam gdzie to możliwe historyk prawa powinien z ustalonego doświadczenia historycznego próbować wyciągać wnioski na przyszłość. Jeżeli jakaś regulacja funkcjonowała w przeszłości i przyniosła określone skutki, pozytywne lub negatywne, warto ocenić obecny stan prawny przez jej pryzmat, a tym bardziej warto przez ten pryzmat postawić jakieś postulaty zmian istniejącego stanu prawnego lub ocenić zmiany proponowane przez innych. Na przykład jeżeli tak niedawno w Polsce prowadzone były prace legislacyjne nad zapisem windykacyjnym lub darowizną na wypadek śmierci, dobrze byłoby, aby historycy prawa przypomnieli instytucje legatum per vindicationem lub donatio mortis causa. Argumentem przeciw nie może być tu, że przecież w literaturze światowej opracowano na ten temat obszerne monografie, prawnik bowiem niebędący historykiem prawa zapewne nawet nie będzie próbował do nich dotrzeć $i$ jeśli nawet dowie się o ich istnieniu, nie znajdzie czasu na ich lekturę. Z kolei syntetyczna praca historyka zawierająca odniesienia do proponowanej regulacji może zostać dostrzeżona i wzięta pod uwagę. Tu nie tylko tradycyjnie przyjmowana perspektywa prawnoporównawcza, ale także historyczna może okazać się cenna.

I w tym aspekcie autorka podołała zadaniu i nie poprzestała na samej tylko retrospekcji i suchym opisie współczesnego przedawnienia roszczeń. Główne zagadnienie ratio przedawnienia zostało podjęte porównawczo $\mathrm{w}$ trzech systemach prawnych i okazało się, że da się wykazać między nimi spore podobieństwa i wyprowadzić wniosek, że doświadczenie tych systemów jest zasadniczo spójne. Sama ta ratio jest bardzo złożona, a wprowadzenie norm dotyczących przedawnienia przede wszystkim staje się elementem budowania równowagi stron, a zatem główną ratio przedawnienia jest regulacja relacji dłużnika $\mathrm{z}$ wierzycielem. W każdym z tych systemów łatwo dostrzegalny jest nałożony na wierzyciela obowiązek staranności przejawiającej się w sprawnym, niezwłocznym, terminowym dochodzeniu swoich praw. We wszystkich tych systemach autorka doszukała się argumentów na rzecz tezy, że przedawnienie jest reakcją na swego rodzaju nadużycie prawa, a w braku przedawnienia zakaz nadużycia prawa może być surogatem tej instytucji. Wykazała również konieczność przyjęcia bardzo dużego stopnia elastyczności w regulacji przedawnienia.

Przykładem rozsądnej propozycji na przyszłość są uwagi dotyczące stawianego przez wielu we Francji i w Polsce postulatu wprowadzenia ogólnej regulacji terminów zawitych. Prima facie postulat ten wydaje się trafny. Autorka, podkreślając niezbędną elastyczność, zauważa jednak, że wprowadzenie takiej regulacji byłoby akceptowalne, o ile łączyłoby się z badaniem poszczególnych przypadków występowania terminów zawitych i rewizją ich obecnej regulacji w zestawieniu z przepisami ogólnymi (ukształtowanie regulacji terminów zawitych na wzór regulacji przedawnienia). Wyniki badań 
pozwoliły także na krytyczną ocenę postulatu daleko idącego ujednolicenia terminów przedawnienia i uproszczenia ich struktury.

\section{VI}

Rozprawa J. Kruszyńskiej-Koli stanowi ważną i godną rozważenia propozycję prowadzenia badań historycznoprawnych, a zwłaszcza fakt sukcesu tej pracy doktorskiej (pierwsza nagroda) w prestiżowym konkursie Państwa i Prawa na najlepsze prace doktorskie potwierdza, że wysiłek autorki został doceniony nie tylko przez historyków prawa. Zresztą druga z recenzji w przewodzie doktorskim pochodziła od cywilisty dr hab. Piotra Tereszkiewicza i także była bardzo pozytywna, a uzasadnienie sądu konkursowego mocno podkreśla walory doktoratu. Praca została opublikowana w prestiżowym wydawnictwie (C.H. Beck) i serii (Monografie Prawnicze), co dodatkowo wzmacnia jej szansę na dostrzeżenie na rynku i sukces także w wymiarze komercyjnym, co nie jest częste wśród historyków prawa. Trudno oczekiwać wyraźniejszych dowodów uznania, można nawet z zazdrością powiedzieć, że wielu z nas marzy o takim sukcesie. Z pewnością przełoży się to na większą rozpoznawalność autorki i poczytność jej następnych prac. Pytanie tylko, czy ścieżka przyjęta przez nią jest jedyną drogą polepszenia komunikacji historii prawa i prawa pozytywnego. Czy wobec tego rzeczywiście jako historycy prawa jesteśmy skazani na prace $\mathrm{w}$ istocie interdyscyplinarne, jeżeli chcemy być dostrzeżeni poza własnym hermetycznym środowiskiem? Myślę, że znakomita większość historyków prawa oburzyłaby się na taką sugestię i odrzuciłaby oczekiwanie tak obszernej i wnikliwej analizy prawa współczesnego w nawiązaniu do własnych badań historycznych. Postulat, aby w ten sposób przygotowywać rozprawy historycznoprawne, nawet jeśli w pewnym stopniu uzasadniony, jest raczej trudny do realizacji. Myślę jednak, że wielu z nas odpowiada kierunek obrany przez J. Kruszyńską-Kolę i może potraktować jej rozprawę jako wzorcową dla własnych prac.

\section{Bibliografia}

Gajda, Ewa i Lubińska, Bożena. Łacińska terminologia prawnicza. Ignorantia iuris nocet. Toruń: Towarzystwo Naukowe Organizacji i Kierownictwa „Dom Organizatora”, 2014.

Kruszyńska-Kola, Joanna. Ratio przedawnienia. Warszawa: Wydawnictwo C.H. Beck, 2020.

Kupiszewski, Henryk. Prawo rzymskie a współczesność. Kraków-Bielsko-Biała: Wydawnictwo Od.Nowa, 2013.

Kuryłowicz, Marek. Prawo rzymskie. Historia, tradycja, współczesność. Lublin: Wydawnictwo Uniwersytetu Marii Curie-Skłodowskiej, 2003.

Palmirski, Tomasz, red. Digesta Iustiniani. Digesta Justyniańskie. Tekst i przekład. Kraków: Poligrafia Salezjańska, 2013-2017.

Sobczyk, Marek. „Prawo rzymskie przed sądami Wspólnot Europejskich”. Studia Prawnoustrojowe 7 (2007): 279-94. 
Wołodkiewicz, Witold. „Łacińskie paremie prawnicze w polskiej praktyce prawnej”. W: Regulae iuris. Łacińskie inskrypcje na kolumnach Sąu Najwyższego Rzeczpospolitej Polskiej, red. Agnieszka Kacprzak, Jerzy Krzynówek i Witold Wołodkiewicz, 7-30. Warszawa: Wydawnictwo C.H. Beck, 2001.

Wołodkiewicz, Witold. „Prawo rzymskie w XXI wieku”. W: Europa i prawo rzymskie. Szkice z historii europejskiej kultury prawnej, 192-9. Warszawa: Wolters Kluwer Polska, 2009.

\section{Akty normatywne}

Ustawa z dnia 13 kwietnia 2018 r. o zmianie ustawy - Kodeks cywilny oraz niektórych innych ustaw (Dz.U. 2018 poz. 1104).

\section{Orzecznictwo}

Wyrok SN z dnia 24 czerwca 2010 r., IV CSK 67/10.

Postanowienie SN z dnia 20 marca 2014 r., I CSK 404/13.

Wyrok SN z dnia 17 listopada 2014 r., III KK 236/14.

Wyrok SN z dnia 9 sierpnia 2016 r., II CSK 760/15.

Wyrok SN z dnia 27 lipca 2018 r., V CSK 401/17.

Wyrok SN z dnia 16 maja 2019 r., III CSK 40/17.

Postanowienie SN z dnia 26 listopada 2019 r., IV CSK 418/18.

Wyrok SN z dnia 31 marca 2020 r., II CSK 124/19. 